\title{
Discussion on Design of Art Gallery in Local Colleges and Its Value Orientation of Regional Culture
}

\author{
Liying Li \\ Huangggang Normal University \\ Huanggang, China, 438000
}

\author{
Hai Cheng* \\ School of Fine Arts \\ Huanggang Normal University \\ Huanggang, China, 438000 \\ *Corresponding author
}

\begin{abstract}
The coming of "fine arts era" makes art gallery become the place for quality-oriented education. Art galleries in colleges develop rapidly under the leadership of professional fine arts colleges. According to the common selection of worldwide higher education development, demands of local economic and social development and objective requirements of survival and development of colleges, the education of local colleges values regional culture and serves local places. The combination of construction of art gallery in local colleges with expansion of regional culture is the objective requirements for colleges to survive and develop, promoting the social value system of local culture.
\end{abstract}

\section{Keywords -art gallery; local colleges; value orientation}

\section{DEVELOPMENT STATUS OF ART GALLERY IN LOCAL COLLEGES}

With the management system reform of higher education, local colleges become the "two body" of "pyramid" of colleges. The construction and development of local colleges have close relationship with local economic and social development. The service of local places is the guarantee of colleges to obtain survival basis, strengthen school-running vitality and realize self-value [1]. Local colleges fail to closely link with local society. The principal of University of Wisconsin Van Hire addresses, "Service should be the only rationality of Universities". The service of local colleges for the society becomes the common choice of higher education development in countries of the world.

Local colleges have diversified forms to serve the society. The primary function of art gallery in colleges is the publication and popularization of education and research results. From the perspectives of professional teaching, aesthetic education popularization and social communication, art galleries in local colleges integrate regional features and manifest regional culture, significant for students' education. The educational functions of art gallery make students understand the overall value of regional culture in contemporary life and guide them to improve aesthetic

Innovation activity project of college students in experimental teaching demonstration center of Huanggang Normal University in 2016 (No. zx201602) standard.

\section{RESEARCH AND DISCUSSION ON CASES OF ART GALLERY IN LOCAL COLLEGES}

The primary task of art gallery in colleges is to show and popularize research results of education. Art galleries are indispensable in professional fine arts colleges and play an increasingly important role in comprehensive colleges. Fine arts colleges and comprehensive universities establish art galleries successively and the orientation of art galleries in colleges has deviations at all levels. They regard art gallery as "exhibition hall", value exhibition and neglect education, so that the education and researches on art gallery stay superficial [2]. The premise of clear orientation of art gallery is to understand local cultural tradition and integrate local cultural connotation in the design of art gallery.

\section{A. Wen Yiduo Art Gallery in Huanggang Normal University}

Wen Yiduo Art Gallery of Huanggang Normal University in Hubei Province belongs to fine arts college and covers an area of 1,000 square meters. The original family home of Wen Yiduo is in Huanggang of Hubei Province. Wen Yiduo was interested in classical poems and fine arts from a child and engaged in education in a lifetime. The art gallery is named after him and it influences each people in Huanggang Normal University. It is the foundation of development of contemporary colleges to inherit and carry forward academic spirit and reflect on learning attitude. The art gallery is divided into the exhibition area of Mr. Wen Yiduo's academic research and the flow exhibition area of works of teachers and students. The design style refers to the culture of architectural decoration in Jingchu. The design of entrance reflects the sense of wholeness and harmonious beauty of exhibition hall. It uses gray tone which integrates with natural environment and regional characteristics. The skillful use of "texture" gives visitors visual impact. The circulation design starts from "people" and avoids negative phenomena of convection of people, complex routes and aesthetic fatigue.

Human resources in regional culture are important materials for local colleges to build characteristic discipline. 
Meanwhile, the research on excellent human resources in regional culture and the creation of large numbers of research results relevant to inheritance and spread of regional culture greatly enrich the development of the humanities [3].

Urban art culture with local characteristics has full-bodied inheritance and integrates cultures of historical civilization and modern civilization. Historical culture with different characteristics reflects the lifestyle of the public, referring to the integration of tangible and intangible cultural heritage. The art culture on campus is unique culture. Art education is the reflection of campus culture and greatly promotes other professional courses. The training of excellent students depends on campus environment. The beautiful campus culture is inseparable from art edification. Art education on campus plays an irreplaceable role in cultural construction of colleges. The design of art gallery adds new elements and philosophies. Local characteristics and green nature philosophy integrate in art gallery. Visitors feel the local cultural connotation in appreciating artistic works. Urban art culture with local characteristics has full-bodied inheritance and integrates cultures of historical civilization and modern civilization. It contains historical culture with different characteristics and reflects the lifestyle of the public, referring to the integration of tangible and intangible cultural heritage.

\section{B. Design of Art Gallery of Guangzhou Maritime Institute}

The multifunctional classroom with an area of more than 400 square meters in Guangzhou Maritime Institute is transformed into art gallery. The characteristic of it is "navigation" culture. Under the premise of meeting service space, the original space is divided into entrance hall, exhibition room and gallery. It adds interlayer space and increases the exhibition scope of design works and improves the appreciation environment. With the theme of "sailing place", the wall space at the entrance of exhibition hall takes the "bow" as basic element to build through geometric form, combination of faces and overlap combination. The thick mooring rope, bitt and lighting create quiet appreciation space, form marvelous effect of visual appreciation and deeply express navigation culture. "Fig. 1-2"

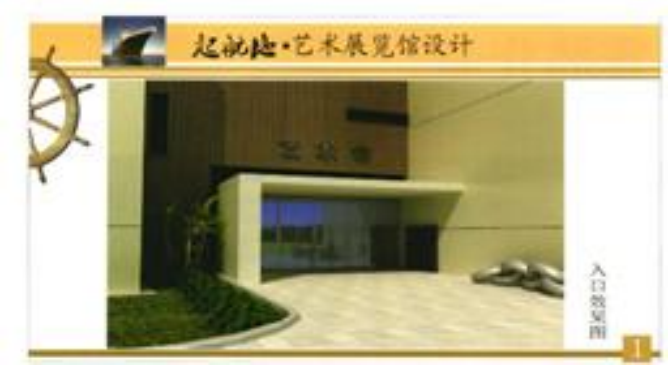

Fig. 1. Effect picture of exhibition hall of Guangzhou Maritime Institute.

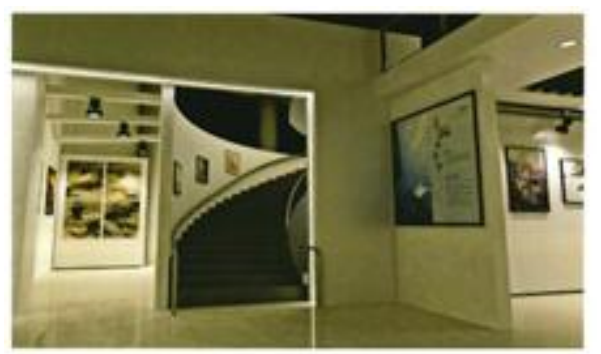

Fig. 2. Effect picture of exhibition hall of Guangzhou Maritime Institute..

The culture full of the spirit of the times reflects the civilization degree, charm and potential of an area. The development of colleges depends on cultural deposits. Cultural force is intangible and closely relates to the cultural development of colleges. Art galleries of local colleges integrate with regional cultural resources, cultural atmosphere, cultural development and its development level to improve the attraction and competitiveness of colleges [4]. The design of art gallery is the beautiful expression of exhibition hall and reflects cultural atmosphere on campus, image, aesthetic taste and value orientation. The design of exhibition hall closely links to the "navigation" culture, depends on the unique position advantage of "Maritime Silk Road" to make the art gallery have imperceptible function. As an important place for external exchange, teaching and scientific research of colleges, art galleries can manifest characteristic campus culture and inherit historical context of colleges.

\section{Art Gallery of Hebei University}

The school of art in Hebei University was established in 2000. The art gallery in it is the first one in local colleges of Hebei province. The art gallery carries forward regional cultural characteristics. The design integrates its unique style: art gallery locates in the school of art with one exhibition hall in the north and the south respectively to display works of teachers and students; a small exhibition hall locates in the north building to display eaves tile from the lower capital of the Yan State, the Ding porcelain researched by Chen Wenzeng and the simulation paintings and calligraphy works of masters from past dynasties of China. Eaves tile from the lower capital of the Yan State in Yi County of Hebei Province is one of the three regional eaves tiles in pre-Qin period. Ding porcelain originates from Hebei and refers to outstanding porcelain in Song Dynasty. Local resources are applied to highlight school-running characteristics. Local colleges depend on division of disciplines, scientific research power and local historical and cultural tradition to create characteristic teaching and scientific research to promote the integrated improvement of talents. "Fig. 3" "Fig. 4" 


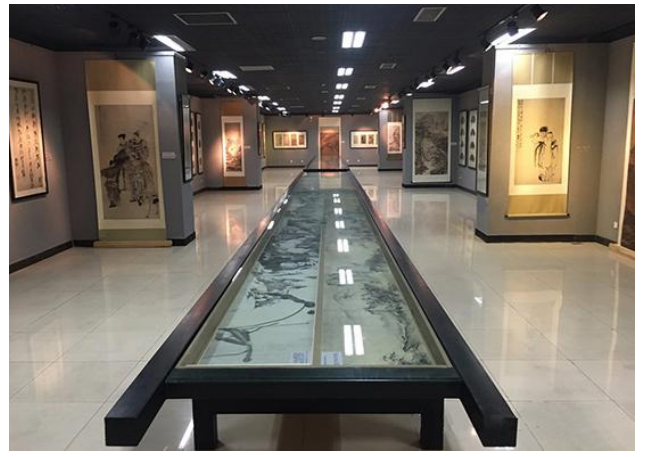

Fig. 3. Display room of simulation paintings and calligraphy works of masters in past dynasties of China.

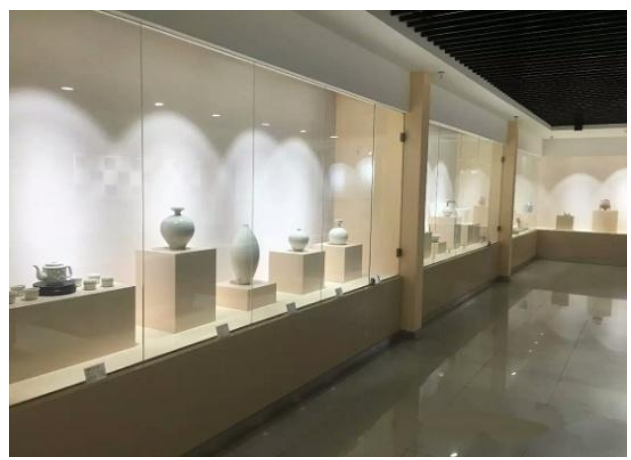

Fig. 4. Display room of Ding Porcelain researched by Chen Wenzeng.

The spiritual strength contained in regional culture has been transformed into real competitiveness and productivity, playing an imperceptible role in cultural construction of colleges and referring to the guarantee of social sustainable development. Regional culture is a valuable spiritual treasure and social resources. It has profound historical and realistic significance for local colleges deeply excavate and research regional culture, inherit and carry forward excellent tradition, in order to let regional culture better serve modern education and promote cultural construction of colleges. Regional cultural resources integrate in teaching in colleges, promote contemporary college students to pursue value orientation and establish ideological level and accumulate knowledge. The training of talents in local colleges makes development form ceaseless internal motivation. Local colleges have enough reasons to prove the training of self-awareness improves the potential to train distinctive talents.

\section{VALUE ORIENTATION OF ART GALLERY IN LOCAL COLLEGES}

As the highest school of prefecture-level city, local colleges do academic research and train high level talents, assuming the sacred mission of improving cultural quality of people. The correct value orientation of art gallery in colleges must update ideas, improve policies and innovate in management mode. Ideally, it is people-oriented, protects interests of students and develops education. UNESCO clearly addresses in the Declaration of the World Conference on Higher Education, in the world changing with each passing day, higher education obviously needs student-oriented new perspective and pattern. Decision makers of the country and colleges value students and their demands and regard them as main and responsible participators in higher education reform. Students' interests relate to colleges, meanwhile, students are indispensable force of college development [5]. Art galleries of local colleges are media to display the talents of students. The correct value orientation of art galleries greatly promotes the development of college and students.

Regional culture is excellent national culture of our country and integrates material and spiritual wealth created by people in the long-term social practice. Art galleries of colleges display people's spirit, idea, psychology and characters. Cultural characteristics of local colleges closely relate to regional culture. Cultures differ in different regions. The cultural mainstream of contemporary colleges is formed by diversified regional cultures. Education of local colleges cannot do without regional culture. Regional culture is important for local colleges to construct characteristic discipline. Local colleges radiate campus culture and bring positive and healthy mainstream ideology and culture in local places to realize cultural innovation and development.

Artistic works are displayed, researched and collected in art galleries. Art galleries undertake the social responsibility and historical mission of people's quality-oriented education and external cultural exchange and the development of contemporary art. The design of art gallery in local colleges roundly reflects local culture and depends on local characteristics and campus culture. Art galleries play a positive role in academic development of colleges, fine arts education in middle and primary school and improvement of citizens' cultural quality.

\section{CONCLUSION}

With the development of times, researches on value of regional history and culture by local colleges have made large numbers of excellent achievements, laying a solid foundation for local colleges to further research it. However, at present, the depth and breadth of introduction and researches on regional culture by local colleges are far from adequate. In orientation of regional value of art gallery design, colleges need to observe roundly, especially make in-depth researches on character, form, peculiarity and protection, construction, development and utilization of regional history and culture.

\section{REFERENCES}

[1] Yang Deshan. Analysis on Paths for Local Colleges to Serve Local Places [J], Chinese University Technology Transfer, 2010, (07): 48-50

[2] Wang Min. How Art Galleries Walk into Colleges [J], Art and Literature for the Masses, 2012,(21):255+234

[3] Cao Yumin. Discussion on Regional Culture and Characteristic School Running of Local Colleges [J], Journal of National Academy of Education Administration, 2010,(09):69-72+94

[4] Ma Jing. Cultural Design of Art Gallery [J], Art Observation, 2015, (02):96-97

[5] Wang Fuping, Feng Dong. Conflicts and Avoidance of Value Orientation of New Specialty in Local Colleges under the Interest Perspective $[\mathrm{J}]$, Journal of Higher Education Management, 2014,(05):79-82 